\title{
MAGE-A1, Her-2/neu, FBP Peptides Cancer Vaccine
}

National Cancer Institute

\section{Source}

National Cancer Institute. MAGE-A1, Her-2/neu, FBP Peptides Cancer Vaccine. NCI

Thesaurus. Code C62775.

A synthetic cancer vaccine comprised of multiple peptides derived from MAGE-1A, Her-

$2 /$ neu, and folate binding protein (FBP), with potential immunostimulating and antineoplastic properties. MAGE-A1, Her-2/neu, and FBP proteins are simultaneously over-expressed in various cancer cell types, such as epithelial ovarian cancer. The MAGEA1, Her-2/neu, FBP peptides cancer vaccine includes the peptides MAGE-A1:161-169, FBP:191-199, Her-2/neu:369-377, MAGE-A1:96-104, and Her-2/neu:754-762. Vaccination with this cancer vaccine may activate the immune system to mount a cytotoxic T-cell (CTL) response against tumor cells expressing the corresponding antigens, resulting in tumor cell lysis. 